\title{
I koma frå fengselet
}

Nye medisinar mot psykiske lidingar kjem mange pasientar til gode. Men desse medikamenta kan ha til dels sjeldne, men alvorlege biverknadar som krev tverrfagleg tilnærming. Retningsliner for undersøkingar ved oppstart og vedlikehaldsbehandling kan vere spesielt viktig i slike tilfelle.

Se kommentar side 285 og kunnskapsprøve på www.tidsskriftet.no/quiz

\author{
Håvard A. Sæverud* \\ hvsv@uus.no \\ Per Gerlyng \\ Medisinsk klinikk \\ Lovisenberg Diakonale Sykehus \\ 0440 Oslo \\ * Nåværende adresse: \\ Lungemedisinsk avdeling \\ Oslo universitetssykehus, Ullevål \\ 0407 Oslo
}

Ein 42 år gammal mann vart lagt inn frå fengsel ein måndag morgon. Ambulansetenesta opplyste at han om morgonen vart funnen komatøs og kald i cella si. Han skulle ha vore sett fredag, men ein visste lite om korleis det hadde vore med han i helga. Tidlegare sjukehistorie var ikkje kjent.

Søstera til mannen fortalte at han $i$ utgangspunktet stort sett hadde vore frisk, men at han hadde hatt lette depressive plager. Ho hadde snakka med han seks dagar tidlegare. Han hadde då gitt uttrykk for at han kjende seg litt slapp og lurte på om han heldt på å verte sjuk.

Dei fyrste målingane viste temperatur på $34,2^{\circ} \mathrm{C}$, blodtrykk $95 / 59 \mathrm{~mm} \mathrm{Hg}$, ein respirasjonsfrekvens 20/min, noko som gav ein perifer saturasjon på 88-90\%, med $91 \mathrm{O}_{2}$ via maske. Han var komatøs, Glascow Coma Scale 3, pupillane var sidelike og reagerte normalt på lys, direkte og indirekte. Han var ikkje nakkestiv, og det var ingen funn når det gjaldt klinisk status elles. EKG viste sinusrytme $83 / \mathrm{min}$. I arteriell blodgass var $\mathrm{pH}$ 6,89 (7,35-7,45), pCO (a) 3,58 kPa $(4,7-6,0$ $\mathrm{kPa}), \mathrm{pO}_{2}(\mathrm{a}) 9,96 \mathrm{kPa}(11,0-14,0 \mathrm{kPa}), \mathrm{HCO}_{3}$ $5,0 \mathrm{mmol} / \mathrm{l}(22,0-26,0 \mathrm{mmol} / \mathrm{l})$, baseoverskot -27,4 (-3-+3), s0 (a) 87,7\%, noko som passer godt med hypoksemi og metabolsk acidose med respiratorisk kompensasjon.

Vanleg blodsukkerapparat viste «high». Urinstiks viste store mengder glukose og ketonar, dessutan noko raude blodceller og protein. Blodprøvene viste òg at han hadde nyresvikt, med eit kreatininnivå på 173 umol/l (60-100 $\mathrm{mmol} / \mathrm{l})$. Serum-glukose vart målt til 38,8 mmol/l (4,0-6,0 mmol/l). Det var ikkje teikn til paracetamol eller etanol $i$ blodet.

Det var klart at vi hadde med nyoppdaga diabetes mellitus med ketoacidose å gjere, og det kliniske biletet passa best med type 1diabetes. Pneumoni med sepsisutvikling kunne vere utløysande årsak. Supplerande undersøkingar stadfesta dette - det var høge nivå av inflammasjonsmarkørar i serum og utbreidde infiltrat bilateralt på røntgen thorax. Det vart sett i gang sepsisbehandling med antibiotika i tillegg til insulininfusjon for å korrigere ketoacidosen.

Det følgde med ei medisinliste frå fengselet. Mannen stod på Cipralex (escitalopram) 20 $m g \times 1$, Zyprexa (olanzapin) 7,5 $\mathrm{mg} \times 1$ vesp., Sobril loksazepam) $10 \mathrm{mg} \times 3$, Pulmicort (budesonid) $200 \mu \mathrm{g} /$ dose, ukjent intervall, og Bricanyl (terbutalin) $5 \mathrm{mg} /$ dose, ukjent intervall.

Studiar har vist at alle antipsykotika gir auka risiko for utvikling av diabetes mellitus, men at risikoen er størst for atypiske antipsykotika. Aller størst ser risikoen ut til å vere for klozapin og olanzapin, det gjeld utvikling av hyperlipidemi, vektauke og forverring av preeksisterande diabetes mellitus (1-4). Det er haldepunkt for å tru at desse medikamenta kan utløyse dette også hos dei som ikkje har diabetes frå tidlegare, og det er rapportert tilfelle der diabetisk ketoacidose er debutsymptomet (5-7). Data er noko meir usikre når det gjeld risperidon og quetiapin, medan datagrunnlaget er for lite til at ein førebels kan seie noko om ziprasidon og aripiprazol (8). Tre av fire pasientar som får denne biverknaden, ser ut til å få han i løpet av dei første seks månadane - men det er verdt å merke seg at det er rapportert tilfelle fleire år etter oppstart. Ein har ikkje funne nokon sikker samanheng mellom medikamentdose og glukosenivå.

Pasienten vakna etter ei stund noko til og var uroleg. Respiratorisk vart han ikkje betre.
Han fekk først behandling med kontinuerleg positivt luftvegstrykk (CPAP), men samarbeidde dårleg om dette. På grunn av gradvis dårlegare respiratorisk funksjon vart han intubert om kvelden innkomstdagen. I tillegg var han vedvarande sirkulatorisk ustabil og fekk store mengder væske i tillegg til pressorsubstansar for å oppretthalde adekvat sirkulasjon. Han utvikla oliguri og etter kvart anuri.

Han vart tiltakande vanskeleg å oksygenere. Etter eitt døgn i avdelinga vurderte vi situasjonen slik at ekstrakorporal membranoksygenering (ECMO) kunne verte aktuelt. Pasienten vart derfor overflytta til Rikshospitalet.

På Rikshospitalet fekk han dialyse pga. nyresvikt, han vart respiratorbehandla, men trong ikkje ekstrakorporal membranoksygenering. Han fekk behandling med breispektra antibiotika. Alle bakteriologiske prøver var negative, og ein fann ikkje sikkert fokus for infeksjon. Dei initielle røntgenendringane passa med akutt respiratorisk stress-syndrom og gjekk relativt raskt i regress, men med bilaterale restfortettingar. Etter ti dagar vart han overflytta til eit lokalsjukehus $i$ ein annan del av landet og vart etter kvart utskriven derfrå utan insulin.

Nokre dagar etter utskriving frå oss kom det svar på serum-olanzapinprøva - 41 nmol/l (referanseområde ved terapeutisk bruk er 30-200 nmol/l).

Historia kan tolkast som nyoppdaga diabetes mellitus type 1 , alvorleg ketoacidose og sepsis hos ein pasient. Trass i dette vart han etter behandling utskriven utan å trenge insulin. Dette er ikkje typisk for type 1-diabetes. Diverre vart det ikkje teke utredningsprøver for diabetes, difor er antistoffstatusen hans ukjent.

Vi har etterpå vore i kontakt med pasienten, som kan fortelje at han starta med Zyprexa under opphaldet $\mathrm{i}$ fengselet om lag seks månader før han vart innlagt hos oss.

\section{Diskusjon}

Mistanken om at antipsykotika kan verke inn på glukose- og lipidmetabolismen er ikkje ny - allereie i 1950- og 60-åra vart det publisert fleire artiklar der dette kom fram.

Å påvise kausalsamanheng mellom bruk av nevroleptika og nytilkomen diabetes mellitus hos den einskilde pasient er særs vanskeleg. I fleire land har ein hatt behov for å utvikle retningsliner for god klinisk praksis for å oppdage utvikling av diabetes hos mennes- 
ke som har behov for nevroleptika. Desse retningslinene tek for seg kontrollregime og diskuterer indikasjonar for bytte av nevroleptika til medikament med lågare kjent risiko. I løpet av 2004 og 2005 vart det internasjonalt publisert seks slike retningsliner. Desse vart samanlikna i ein artikkel i Canadian Journal of Psychiatry (9). Retningslinene skil seg noko når det gjeld kontrollhyppigheit og om dei skal gjelde berre pasientar som brukar atypiske antipsykotika eller om dei skal gjelde alle som brukar slike middel. Dei skil seg òg noko når det gjeld tidspunkt for tilvising til indremedisinar og ev. medikamentskifte. Dei er likevel i hovudsak samstemte om variablane. Hovudpunkta er oppsummerte i tabell 1, basert på forslaget frå ei breitt samansett amerikansk konsensusgruppe (10).

Så langt vi veit, eksisterer det ikkje offisielle norske retningsliner for korleis dette skal handsamast. Andreassen \& Bentsen argumenterte i ein artikkel i Tidsskriftet i 2004 for at merksemda rundt denne problematikken må aukast (11). Dette er ei oppmoding som truleg må gjentakast.

Vi kan aldri bevise at det var ein kausalsamanheng mellom bruken av olanzapin og ketoacidosen hos pasienten vår. Hovudpoenget er at det med den kunnskapen som $\mathrm{i}$ dag er tilgjengeleg om innverknaden nevroleptika har på glukose- og lipidmetabolismen, er behov for retningsliner for korleis metabolske biverknadar hos denne pasientgruppa skal handsamast. Når land det er vanleg å samanlikne med har fått dette på plass, vil det vere naturleg at dette òg skjer i Noreg.

Saka vart meldt til regionalt legemiddelinformasjonssenter (RELIS). I si tilbakemelding skriv dei: «Hyperglykemi og/eller utvikling eller forverring av diabetes, av og til assosiert med ketoacidose eller koma, inkludert enkelte fatale tilfeller, er sett i meget sjeldne tilfeller ved behandling med olanzapin. I noen tilfeller er forutgående vektøkning rapportert, hvilket kan være en

Tabell 1 Retningsliner ved oppstart av antipsykotisk behandling, etter American Diabetes Association m.fl. (10)

\begin{tabular}{|c|c|c|c|c|c|c|c|}
\hline & $\begin{array}{l}\text { Opp- } \\
\text { start }\end{array}$ & 4 veker & 8 veker & 12 veker & $\begin{array}{l}\text { Kvar } 3 . \\
\text { månad }\end{array}$ & Årleg & $\begin{array}{l}\text { Kvart } \\
\text { 5. år }\end{array}$ \\
\hline Anamnese & $x$ & & & & & $x$ & \\
\hline Vekt (BMI) & $x$ & $x$ & $x$ & $x$ & $x$ & & \\
\hline Midjeomkrins & $x$ & & & & & $x$ & \\
\hline Blodtrykk & $x$ & & & $x$ & & $x$ & \\
\hline Fastande blodglukose & $x$ & & & $x$ & & $x$ & \\
\hline Fastande blodlipidar & $x$ & & & $x$ & & & $x$ \\
\hline
\end{tabular}

disponerende faktor. Hensiktsmessig klinisk overvåkning, spesielt av diabetikere og pasienter med risikofaktorer for utvikling av diabetes mellitus anbefales ved behandling med olanzapin.»

\section{Epilog}

Pasienten vart ved utreise frå lokalsjukehuset tilvist medisinsk poliklinikk lokalt for vidare oppfølging, men han har berre vore følgt av eigen lege. Etter å ha vore i telefonisk kontakt med fastlegen har vi fått greie på at mannen har hatt stabile blodsukkerverdiar på 6-talet utan bruk av antidiabetika i snart to år etter den aktuelle episoden.

Pasienten har gitt samtykke til at artikkelen blir publisert.

\section{Oppgitte interessekonflikter: Ingen}

\section{Litteratur}

1. Lieberman JA, Stroup TS, McEvoy JP et al. Effectiveness of antipsychotic drugs in patients with chronic schizophrenia. N Engl J Med 2005; 353: 1209-23.

2. Newcomer JW, Haupt DW. The metabolic effects of antipsychotic medications. Can J Psychiat 2006 51: 480-91.

3. Birkenaes AB, Birkeland KI, Engh JA et al. Dyslipidemia independent of body mass in antipsychotic-treated patients under real-life conditions. J Clin Psychopharmacol 2008; 28: 132-7.
4. Ader M, Kim SP, Catalano KJ et al. Metabolic dysregulation with atypical antipsychotics occurs in the absence of underlying disease: a placebo-controlled study of olanzapine and risperidone in dogs. Diabetes 2005; 54: 862-71.

5. Koller EA, Cross JT, Doraiswamy PM et al. Pancreatitis associated with atypical antipsychotics: from the Food and Drug Administration's MedWatch surveillance system and published reports. Pharmacotherapy 2003; 23: 1123-30.

6. Goldstein LE, Sporn J, Brown S et al. New-onset diabetes mellitus and diabetic ketoacidosis associated with olanzapine treatment. Psychosomatics 1999: 40: 438-43.

7. Koller EA, Doraiswamy PM. Olanzapine-associated diabetes mellitus. Pharmacotherapy 2002; 22 841-52.

8. Newcomer JW. Second-generation (atypical) antipsychotics and metabolic effects: a comprehensive literature review. CNS Drugs 2005; 19 (suppl 1): 1-93.

9. Cohn TA, Sernyak MJ. Metabolic monitoring for patients treated with antipsychotic medications. Can J Psychiat 2006; 51: 492-501.

10. American Diabetes Association. American Psychiatric Association. American Association of Clinical Endocrinologists. North American Association for the Study of Obesity. Consensus development conference on antipsychotic drugs and obesity and diabetes. Diabetes Care 2004; 27: 596-601.

11. Andreassen OA, Bentsen H. Metabolske og kardiovaskulære bivirkninger av moderne antipsykotika. Tidsskr Nor Lægeforen 2004; 124: $181-2$

Manuskriptet ble mottatt 25.3. 2008 og godkjent 10.9. 2009. Medisinsk redaktør Odd Terje Brustugun.

\section{Kommentar}

\section{Metabolsk og kardiovaskulær helse ved psykiske lidelser}

Det er anslått at personer med alvorlige psykiske lidelser som schizofreni og bipolar lidelse i gjennomsnitt har 25 år kortere forventet levetid enn referansebefolkningen (1). Den viktigste årsaken til denne overdødeligheten er hjerte- og karsykdommer - ikke selvmord. Denne økte risikoen har mange årsaker, blant andre knyttet til lav sosioøkonomisk status, uheldige levevaner og underbehandling av somatisk sykdom og risikofaktorer hos psykiatriske pasienter. $50-80 \%$ av dem med alvorlig psykiatrisk sykdom røyker, og det er anslått at de forbruker $34-44 \%$ av alle sigaretter i USA (2). Også norske tall bekrefter denne tendensen: Forekomsten av kardiovaskulære risikofaktorer som røyking, hypertensjon, fedme, diabetes og dyslipidemi var omtrent dobbelt så høy hos dem med alvorlige psykiske sykdommer som i den generelle befolkningen (3). Personer med alvorlig psykisk sykdom ser ut til å ha en sykdomsassosiert sårbarhet som utsetter dem for betydelig risiko når de eksponeres for det moderne fedmefremmende (obesogene) miljø.
Selv om det er holdepunkter for å anta at de fleste nevroleptika kan medvirke til vektøkning, ser det ut til at klozapin og olanzapin har størst slik effekt. Mekanismene for denne vektøkningen er ikke fullt ut kartlagt, men trolig er en direkte appetittstimulerende virkning via stimulering av $\mathrm{H}_{1}$-histaminreseptor viktig (4). Det kan passe med at de medikamentene som har sterk affinitet til $\mathrm{H}_{1}$-reseptoren, er de der dette er mest aktuelt. I tillegg til, og delvis som en følge av vektøkningen, forverres ofte risikofaktorer 